\title{
Produksi Enzim Selulase Kasar dari Isolat Bakteri B2S8 menggunakan Substrat Brangkasan Jagung dengan Perlakuan Konsentrasi Inokulum dan Komposisi Media yang berbeda \\ Production of Crude Cellulase Enzyme from B2S8 Bacteria Isolate Using Corn Stover Substrate with Inoculum Concentration and Different Media Composition Treatment
}

\author{
Nursatria Purba, Ida Bagus Wayan Gunam*, I Made Mahaputra Wijaya \\ PS Teknologi Industri Pertanian, Fakultas Teknologi Pertanian, Universitas Udayana, Kampus Bukit \\ Jimbaran, Badung, Kode pos : 80361; Telp/Fax : (0361) 701801.
}

Diterima 09 Desember 2019 / Disetujui 20 Januari 2020

\begin{abstract}
The purpose of this study was determined the media and concentration of cellulolytic bacterial isolates to produce high cellulase enzyme activity. Production of crude cellulase enzyme in media and concentration of different bacterial isolate used a factorial Randomized Block Design (RBD) which consist of two factors. The first factor was the media production of different cellulase enzyme consisting of 3 levels, namely media 1, 2 and 3. The second factor was the concentration of bacterial isolate consisting of 5 levels namely 1, 2, 3, 4 and 5\%. This study used a B2S8 cellulolytic bacterial isolate that has the highest value of cellulase enzyme activity and the highest degradation rate of cellulose in previous studied and determined the ability of exoglucanase enzyme activity, endoglucanase enzyme and dissolved protein content produced from cellulolytic bacterial isolate. This study used Carboxymethyl Cellulose (CMC) for enzyme activity test and 1\% corn stover as a substrate on the media to produce crude cellulase enzyme. The result showed that the highest cellulase enzyme activity in the third media and 5\% cellulolytic bacterial inoculum concentration resulted in endoglucanase activity of $0.0332 \mathrm{IU} / \mathrm{mL}$, exoglucanases enzyme activity of $0.0060 \mathrm{IU} / \mathrm{mL}$, dissolved protein content in the amount of $0.5670 \mathrm{mg} / \mathrm{mL}$, the specific endoglucanase activity of $0.0807 \mathrm{IU} / \mathrm{mg}$ and the specific activity of exoglucanase of $0.0123 \mathrm{IU} / \mathrm{mg}$.
\end{abstract}

Keywords: Cellulolytic bacteria, Cellulase enzymes, Enzyme activity, Corn stover.

\footnotetext{
*Korespondensi Penulis:

Email : ibwgunam@unud.ac.id
} 


\section{PENDAHULUAN}

Selulosa tanaman, komponen utama dinding sel tanaman adalah sumber energi terbarukan yang paling melimpah dan murah. Berat kering tanaman mengandung 35-50\% selulosa, 20-35\% hemiselulosa dan 5-30\% lignin. Selulosa tanaman memiliki struktur sangat kristalin yang tidak larut dalam air dan dikelilingi oleh lapisan lignin yang keras. Karena itu, hidrolisis enzimatik selulosa menjadi glukosa sangat sulit dilakukan. Selulase termasuk dalam keluarga besar enzim glikosil hidrolase, termasuk endoglukanase, ekoglukanase dan $\beta$ glukosidase. Mikroorganisme yang diidentifikasi sejauh ini terlibat dalam produksi selulase dan enzim terkait adalah bakteri, beberapa jamur, dan actinomycetes. Organisme selulolitik yang berasal dari jamur menghasilkan selulase dapat digunakan dalam proses produksi, pakan ternak, tekstil, bahan bakar dan industri kimia. Namun, karena pertumbuhan jamur yang lambat, biaya produksi selulase tinggi untuk proses ini. Sebaliknya, kultur bakteri, tumbuh dengan cepat dan memiliki waktu generasi yang pendek dan karakteristik menguntungkan lainnya. Dengan demikian bakteri memiliki potensi penerapan yang baik (Yang et al., 2014).

Salah satu sumber lignoselulosa yang melimpah di alam adalah tanaman jagung (Anindyawati, 2010). Di daerah indonesia bagian Timur, tanaman jagung selain digunakan sebagai pakan segar, dapat juga dikeringkan atau diolah menjadi pakan awet seperti pelet dan disimpan untuk cadangan pakan ternak (Umiyasih, 2008). Di bali, jagung merupakan bahan pangan, sedangkan brangkasan jagung dan tongkolnya biasanya digunakan untuk pakan ternak dan bahkan dibiarkan begitu saja. Hal ini menyebabkan brangkasan jagung tersebut menjadi hasil samping yang kurang termanfaatkan.selulosa yang terkandung pada tanaman umumnya dalam bentuk lignoselulosa.

Untuk mencapai degradasi enzimatik dalam produksi etanol oleh hidrolisis enzimatik, diperlukan proses pretreatment. Beberapa metode telah diperkenalkan untuk pretreatment bahan lignoselulosa sebelum hidrolisis enzimatik. Metode-metode ini diklasifikasikan menjadi pretreatment fisik, pretreatment fisikokimia, pretreatment kimia, dan pretreatment biologis untuk meningkatkan hidrolisis enzimatik dari bahan limbah lignoselulosa (Gunam et al., 2019). Pretreatment merupakan tahapan yang penting dalam konversi biokimia dari biomassa lignoselulosa menjadi contohnya Biofuel. Tahapan tersebut mengharuskan untuk merubah struktur biomassa selulosa agar akses ke selulosa menjadi lebih tinggi untuk enzim supaya dapat merubah menjadi gula yang dapat difermentasi (Mosier et al., 2005). Oleh karena itu, proses delignifikasi yang dipilih adalah konsentrasi $\mathrm{NaOH} 4 \%$, waktu perendaman selama 8 jam pada suhu kamar (Gunam et al., 2019).

Produksi enzim selulase dipengaruhi oleh beberapa faktor seperti suhu, kelembaban, konsentrasi substrat, sumber karbon, $\mathrm{pH}$ dan konsentrasi inokulum (Coperland, 2000). Suhu dan $\mathrm{pH}$ optimum dalam produksi enzim selulase adalah $36,9^{\circ} \mathrm{C}$ dan $\mathrm{pH}$ 6,9 selama 3 hari (Kusumaningrum et al., 2019). Sumber karbon berperan penting dalam metabolisme sel karena berfungsi sebagai sumber energi dan element struktural sel fungi. Glukosa, suktrosa, fruktosa, maltosa dan pati dapat digunakan sebagai sumber C untuk produksi selulase (Hoa dan Hung, 2013). Dalam media pertumbuhan garam-garam mineral seperti $\mathrm{KNO}_{3}$, $\mathrm{KH}_{2} \mathrm{PO}_{4}, \mathrm{MgSO}_{4} .7 \mathrm{H}_{2} \mathrm{O}$ digunakan sebagai nutrient untuk membantu pertumbuhan sel sedangkan logam kalium pada $\mathrm{KNO}_{3}$ dan Magnesium pada $\mathrm{MgSO}_{4} .7 \mathrm{H}_{2} \mathrm{O}$ merupakan kofaktor bagi aktivitas enzim selulase 
(Pratiwi, 2008). Inokulum merupakan populasi mikroorganisme atau sel dalam bentuk bahan padat atau cair yang ditambahkan kedalam medium fermentasi. Kriteria inokulum yang perlu diperhatikan adalah kultur mikroba bebas dari kontaminan dan tersedia dalam jumlah yang cukup untuk tercapainya proporsi inokulum dengan medium fermentasi (Sood et al., 2011).

Berdasarkan hal di atas, dilakukan penelitian produksi enzim selulase dari bakteri isolat B2S8 dengan menggunakan substrat brankasan jagung. Pada penelitian ini dievaluasi variabel yang mampu mempengaruhi produksi enzim selulase, dari bakteri ini yaitu media produksi dan konsentrasi inokulum bakteri B2S8 untuk menghasilkan aktivitas enzim yang tinggi.

\section{METODE PENELITIAN}

\section{Tempat dan Waktu}

Penelitian dilakukan di Laboratorium Bioindustri dan Lingkungan, Laboratorium Mikrobiologi, dan Laboratorium Analisis Pangan, Fakultas Teknologi Pertanian, Universitas Udayana. Penelitian dilaksanakan Juli-September 2019.

\section{Bahan dan Alat}

Bahan yang digunakan dalam penelitian ini yaitu: brankasan jagung dari petani jagung di daerah Sanur, isolat bakteri selulolitik B2S8 yang diperoleh dari penelitian sebelumnya, Carboxymethyl Cellulosa (CMC) (MERCK), $\mathrm{K}_{2} \mathrm{HPO}_{4}$, $\mathrm{KH}_{2} \mathrm{PO}_{4}, \mathrm{NaCl},\left(\mathrm{NH}_{4}\right)_{2} \mathrm{SO}_{4}, \mathrm{MgSO}_{4} .7 \mathrm{H}_{2} \mathrm{O}$, $\mathrm{MnSO}_{4} .7 \mathrm{H}_{2} \mathrm{O}, \mathrm{CaCl}_{2 .} 2 \mathrm{H}_{2} \mathrm{O}$, yeast extract, $\mathrm{NaOH}, \mathrm{CaCl}_{2}, \mathrm{pH}$ buffer $4, \mathrm{Ph}$ buffer 7 , $\mathrm{NH}_{4} \mathrm{NO}_{3}, \mathrm{FeCl}_{3} .6 \mathrm{H}_{2} \mathrm{O}$, peptone, reagen asam dinitro salisilat (DNS), CuSO4 (Merck), natrium kalium tatrat (Merck), Reagen FolinCiocalteu (Merck), buffer sodium sitrat, kertas penyaring (whatman no.1), akuades, alkohol $70 \%$, amonium sulfat.

Peralatan yang digunakan dalam penelitian ini yaitu: gelas ukur, corong pemisah, UV-Vis Spektrofotometer (Thermo scientific), $\mathrm{pH}$ meter (Schott instrumen), autoclave (Hirayama), laminar air flow (Wina Airflow), inkubator (Memmert), vortex (Maxi Max II), gelas ukur (Pyrex), Erlenmeyer (Herma), tabung reaksi (Pyrex), termometer, pipet mikro (Socorex), pipet tetes, microtube, bunsen, magnetic stirrer (Precisdig), hot plate, timbangan analitik (Shimada), penjepit, labu ukur (Iwaki), botol duran, kapas, aluminium foil, erlenmeyer 250 $\mathrm{mL}$, Erlenmeyer $1000 \mathrm{~mL}$, ependorf, blender, beaker glass, saringan 60 mesh, blue tips, yellow tips, alkoholmeter.

\section{Rancangan Percobaan}

Rancangan percobaan yang digunakan ialah Rancangan Acak Kelompok (RAK). Percobaan ini merupakan percobaan faktorial dengan dua faktor. Faktor pertama ialah jenis media $(\mathrm{M})$ yang terdiri dari tiga level, disajikan pada tabel 1 yaitu M1 sebagai media 1, M2 sebagai media 2 dan M3 sebagai media 3. Faktor kedua ialah jumlah inokulum bakteri (S) yang terdiri dari tiga level, yaitu $\mathrm{S} 1$ jumlah inokulum bakteri $1 \%, \mathrm{~S} 2$ dengan jumlah inokulum bakteri sebanyak 2\%, S3 dengan jumlah inokulum bakteri sebanyak $3 \%$, S4 dengan jumlah inokulum bakteri sebanyak $4 \%$ dan S5 dengan jumlah inokulum bakteri sebanyak $5 \%$.

Berdasarkan faktor diatas diperoleh 15 kombinasi perlakuan, yang masingmasing perlakuan diulang sebanyak 2 kali berdasarkan waktu pelaksanaannya, sehingga diperoleh 30 unit percobaan. Data obyektif yang diperoleh dianalisis dengan Analysis of Variance (ANOVA) dan apabila terdapat pengaruh perlakuan terhadap parameter yang diamati, maka dilanjutkan dengan uji Beda Nyata Jujur (BNJ) menggunakan perangkat lunak Minitab 17. Perlakuan terbaik ditentukan dengan perlakuanyang menghasilkan rendemen tertinggi, kadar saponin tertinggi dan ketinggian busa 
tertinggi.

\section{Persiapan Isolat dan Substrat}

Isolat potensial terbaik bakteri selulolitik B2S8 didapatkan dari Laboratorium Bioindustri dan Lingkungan Fakultas Teknologi Pertanian Universitas Udayana, isolat ini sudah melalui uji konfirmasi enzim selulase spesifik dari penelitian sebelumnya yang dilakukan oleh Nababan et al., (2019). Kemampuan isolat bakteri selulolitik tersebut dalam menghasilkan enzim selulase telah melalui tahap pengujian kualitatif yaitu dengan pengukuran zona bening sehingga diperlukan pengujian kualitatif lanjutan guna untuk mengetahui kemampuan isolat bakteri selulolitik tersebut dalam menghasilkan enzim selulase. Bahan yang digunakan sebagai substrat penelitian ini adalah brangkasan jagung dari petani sanur umur 3 bulan menggunakan batang dan daun yang sudah berwarna coklat tua.

\section{Pengecilan ukuran}

Limbah lignoselulosa brangkasan jagung ditimbang dan dikeringkan dengan menggunakan oven, sampai kadar air $10 \%$. Setelah kering dihancurkan dengan menggunakan alat penggiling hingga menjadi bubuk yang lolos ayakan 60 mesh, selanjutnya diperoleh bubuk lignoselulosa dengan ukuran seragam (Gunam et al., 2019).

\section{Delignifikasi}

Bubuk brangkasan jagung ditimbang $100 \mathrm{~g}$ yang sudah diayak 60 mesh untuk mendapatkan lignoselulosa bubuk yang seragam, kemudian dimasukkan ke dalam wadah dan diberi larutan $4 \% \mathrm{NaOH}$ dengan perbandingan 1:10, direndam selama 8 jam pada suhu kamar. Setelah filtrasi, padatan yang diperoleh dicuci sampai $\mathrm{pH}$ netral dari pencucian diperoleh, diikuti dengan pengeringan dalam suhu oven pada $105^{\circ} \mathrm{C}$ hingga berat konstan (Gunam et al., 2019).

\section{Pembuatan media cair}

Pembuatan media padat untuk uji konfirmasi bakteri selulolitik terdiri dari: $\mathrm{KH}_{2} \mathrm{PO}_{4} 1,36 \mathrm{~g},\left(\mathrm{NH}_{4}\right)_{2} \mathrm{SO}_{4} 1 \mathrm{~g}, \mathrm{MgSO}_{4} .7 \mathrm{H}_{2} \mathrm{O}$ $0,2 \mathrm{~g}, \mathrm{NaCl} 2 \mathrm{~g}$, yeast ekstrak $1 \mathrm{~g}$, $\mathrm{CaCl}_{2} \cdot 2 \mathrm{H}_{2} \mathrm{O} 0,01 \mathrm{~g}, \mathrm{CMC} 5 \mathrm{~g}$, dalam satu liter air destilat pada $\mathrm{pH}$ 6,8-7 yang selanjutnya dicampur dan dipanaskan sampai mendidih sambil diaduk hingga larut lalu dimasukkan ke dalam botol duran 1 liter (Gupta et al., 2012; Dar et al., 2015).

\section{Peremajaan dan perbanyakan sel bakteri selulolitik}

Isolat bakteri B2S8 dilakukan peremajaan dengan menginokulasikan $1 \mathrm{~mL}$ isolat ke setiap Erlenmeyer sebanyak 5 buah yang berisi $100 \mathrm{~mL}$ medium selulolitik yang mengandung CMC 1\%, diinkubasi pada suhu ruang selama 42 jam dan digojog dengan kecepatan $150 \mathrm{rpm}$. Selanjutnya, dilakukan perbanyakan sel dengan menginokulasikan hasil peremajaan ke Erlenmeyer $1000 \mathrm{~mL}$ yang berisi $700 \mathrm{~mL}$ medium selulolitik yang mengandung CMC 1\%, diinkubasi pada suhu ruang selama 72 jam dan digojog dengan kecepatan $150 \quad \mathrm{rpm}$. Selanjutnya disentrifugasi dengan kecepatan $5000 \mathrm{rpm}$ pada suhu $4^{\circ} \mathrm{C}$ selama 20 menit dan dicuci sebanyak 2 kali pengulangan dengan menggunakan $\mathrm{NaCl} 0.85 \%$ dan kemudian diatur $\mathrm{OD}_{660 \mathrm{~nm}}=5$ (Gupta et al., 2012)

\section{Produksi enzim selulase kasar pada media yang berbeda}

Penggunaan brangkasan jagung pada produksi enzim selulase kasar berfungsi sebagai substrat dan sebagai zat penginduksi (inducer) untuk menghasilkan enzim selulase kasar. Sebanyak 15 buah erlenmeyer berisi $100 \mathrm{~mL}$ media cair yang berbeda dengan campuran substrat brangkasan jagung dengan konsentrasi $1 \%$ dilakukan pengulangan sebanyak 2 kali sehingga diperoleh 30 unit percobaan, setelah media (media 1, 2, 3) steril didinginkan pada suhu ruang kemudian 
ditambah pellet sel kultur yang sudah di adjust OD-nya $=5$ pada spektrofotometer panjang gelombang 660nm sebanyak 1, 2, 3, 4 dan 5\% kemudian diinkubasi pada suhu $37^{\circ} \mathrm{C}$ dalam waterbath shaker selama 3 hari
(Pandey et al., 2015). Setelah diinkubasi selanjutnya disentrifugasi dengan kecepatan $5000 \mathrm{rpm}$ selama 20 menit pada suhu $4^{\circ} \mathrm{C}$ (Duza and Mastan, 2013).

Tabel 1. Komposisi media produksi enzim selulase

\begin{tabular}{|c|c|c|}
\hline Media 1 (Macedo et al., 2013) & Media 2 ( Dar et al., 2015) & Media 3 (Atlas, 2010) \\
\hline $\mathrm{KH}_{2} \mathrm{PO}_{4} 6 \mathrm{~g}$ & $\mathrm{KH}_{2} \mathrm{PO}_{4} 1.36 \mathrm{~g}$ & $\mathrm{KH}_{2} \mathrm{PO}_{4} 1 \mathrm{~g}$ \\
\hline $\mathrm{K}_{2} \mathrm{HPO} 43 \mathrm{~g}$ & $\left(\mathrm{NH}_{4}\right)_{2} \mathrm{SO}_{4} 1 \mathrm{~g}$ & $\mathrm{~K}_{2} \mathrm{HPO}_{4} 1 \mathrm{~g}$ \\
\hline $\mathrm{MgSO}_{4} .7 \mathrm{H}_{2} \mathrm{O} 0,1 \mathrm{~g}$ & $\mathrm{MgSO}_{4} 7 \mathrm{H}_{2} \mathrm{O} 0.2 \mathrm{~g}$ & $\mathrm{MgSO}_{4} .7 \mathrm{H}_{2} \mathrm{O} 0,2 \mathrm{~g}$ \\
\hline $\mathrm{CaCl} 20,1 \mathrm{~g}$ & $\mathrm{CaCl}_{2 .} 2 \mathrm{H}_{2} \mathrm{O} 0.01 \mathrm{~g}$ & $\mathrm{CaCl}_{2} 0,02 \mathrm{~g}$ \\
\hline 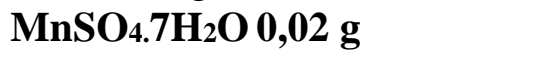 & $\mathrm{NaCl} 2 \mathrm{~g}$ & $\mathrm{NH}_{4} \mathrm{NO3} 1 \mathrm{~g}$ \\
\hline $\mathrm{ZnSO}_{4.7 \mathrm{H}_{2} \mathrm{O}} 0,02 \mathrm{~g}$ & Yeast ekstrak $1 \mathrm{~g}$ & 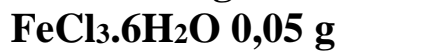 \\
\hline Brangkasan Jagung $10 \mathrm{~g}$ & Brangkasan Jagung $10 \mathrm{~g}$ & $\begin{array}{l}\text { Brangkasan jagung } 10 \mathrm{~g} \\
\text { Peptone } \mathbf{2} \text { g }\end{array}$ \\
\hline
\end{tabular}

\section{Uji aktivitas endoglukonase (CMCase)}

Aktivitas endoglukonase diuji dengan menggunakan campuran reaksi yang mengandung $1 \mathrm{~mL}$ larutan enzim selulase kasar dengan $1 \mathrm{~mL}$ larutan 1\% CMC pada buffer sodium sitrat ( $\mathrm{pH} 5,4)$ diinkubasi pada suhu $50^{\circ} \mathrm{C}$ selama 15 menit reaksi dihentikan dengan menambahkan $3 \mathrm{~mL}$ asam dinitrosalisilat lalu dididihkan selama 5 menit (Dar et al., 2015). Aktivitas selulase dinyatakan dalam satuan internasional yaitu IU/mL. Satu unit merupakan jumlah enzim yang dibutuhkan untuk memecah $1 \mu \mathrm{mol}$ selulosa menjadi gula pereduksi per menit pada kondisi pengujian. Kadar glukosa yang dihasilkan dari hidrolisis selulosa dengan enzim selulase berdasarkan nilai absorbansi pada panjang gelombang $540 \mathrm{~nm}$ dan perhitungan berdasarkan kurva standar (Huang et al., 2012; Duza and Mastan 2013; Dar et al., 2015). Dari data yang didapatkan untuk standar glukosa ini memiliki kemiringan dengan persamaan $\mathrm{y}=\mathrm{ax}-\mathrm{b}$ dengan $\mathrm{x}$ merupakan konsentrasi glukosa $(\mathrm{mg} / \mathrm{mL})$ dan y absorbansi terbaca oleh spektrofotometer UV-VIS pada panjang gelombang $540 \mathrm{~nm}$. Sehingga didapatkan persamaan untuk mengetahui konsentrasi glukosa dalam sampel yaitu: $x=\frac{\mathrm{y}+\mathrm{b}}{a}$

Konsentrasi glukosa dikonversi dalam satuan $\mathrm{IU} / \mathrm{mL}$ :

$1 \mathrm{IU}=1 \mu \mathrm{mol} / \mathrm{menit}$ glukosa yang dihasilkan $=0,18 \mathrm{mg} / \mathrm{menit}$ glukosa

Sehingga,

Aktivitas Enzi $=\frac{\text { Massa glukosa }}{\text { BMG XVeX T }} \mu \mathrm{mol} / \mathrm{menit} \mathrm{mL}(\mathrm{IU} / \mathrm{mL})$

Keterangan:

BMG = Berat Molekul Glukosa $(180 \mathrm{~g} / \mathrm{mol})$

$\mathrm{Ve} \quad=$ Volume Ekstrak Kasar Enzim $(\mathrm{mL})$

$\mathrm{T} \quad=$ Waktu Inkubasi (menit)

\section{Uji aktivitas eksoglukanase (FPase)}

Aktivitas eksoglukanase (FPase) diuji dengan menggunakan campuran reaksi yang mengandung $1 \mathrm{~mL}$ larutan enzim kasar (supernatan) dengan 2 buah $(1 \times 1.5 \mathrm{~cm})$ kertas Whattman No.1 dan $1 \mathrm{~mL}$ buffer sodium sitrat $50 \mathrm{mM}(\mathrm{pH} 5.0)$ diinkubasi pada suhu $50^{\circ} \mathrm{C}$ selama 1 jam. Reaksi dihentikan dengan menambahkan $3 \mathrm{~mL}$ asam dinitrosalisilat lalu dididihkan selama 5 menit. Kadar glukosa yang dihasilkan dari hidrolisis selulosa dengan enzim selulase berdasarkan nilai absorbansi pada panjang gelombang $540 \mathrm{~nm}$ dan perhitungan berdasarkan kurva standar (Dar et al., 2015). Dari data yang didapatkan 
untuk standar glukosa ini memiliki kemiringan dengan persamaan $y=a x-b$ dengan $\mathrm{x}$ merupakan konsentrasi glukosa (mg/mL) dan y absorbansi terbaca oleh spektrofotometer UV-VIS pada panjang gelombang $540 \mathrm{~nm}$. Sehingga didapatkan persamaan untuk mengetahui konsentrasi glukosa dalam sampel yaitu:

$x=\frac{\mathrm{y}+\mathrm{b}}{a}$

Sehingga, $\begin{aligned} \text { Aktivitas Enzim } & =\frac{\text { Massa glukosa }}{\text { BMG X Ve X T }} \mu \mathrm{mol} \\ & / \text { menit mL(IU/mL) }\end{aligned}$

Keterangan:

BMG = Berat Molekul Glukosa $(180 \mathrm{~g} / \mathrm{mol})$

$\mathrm{Ve} \quad=$ Volume Ekstrak Kasar Enzim (mL)

$\mathrm{T}=$ Waktu Inkubasi (menit)

\section{Pengukuran kadar protein terlarut}

Pengukuran kadar protein total dilakukan dengan menggunakan metode Lowry. Larutan yang dibutuhkan yaitu larutan A yaitu $2 \% \quad \mathrm{Na}_{2} \mathrm{CO}_{3}$ dalam $0,1 \mathrm{~N}$ $\mathrm{NaOH}$, larutan B yaitu 2\% Natrium Kalium Tatrat dalan aquades, larutan $\mathrm{C}$ yaitu $1 \%$ CusO4 dalam aquades dan $1 \mathrm{~N}$ Reagen Folin-
Ciocalteu. Pembuatan larutan biuret yang terdiri dari larutan $\mathrm{A}, \mathrm{B}$ dan $\mathrm{C}$ dengan perbandingan 100:1:1. Sampel enzim ekstrak kasar sebanyak $0,15 \mathrm{~mL}$ ditaruh dalam tabung reaksi lalu ditambahkan $3 \mathrm{~mL}$ larutan biuret, diamkan selama 10 menit. Setelah 10 menit ditambahkan larutan Folin sebanyak 0,3 mL divorteks dan didiamkan selama 30 menit. Analisis kuantitatif dilakukan dengan menggunakan instrumen spektrofotometer UV visible pada panjang gelombang $750 \mathrm{~nm}$ (Lowry, 1990).

\section{HASIL DAN PEMBAHASAN}

\section{Aktivitas enzim endoglukanase}

Analisis aktivitas ekstrak kasar selulase dari isolat bakteri B2S8 ini ditentukan dengan mengukur kadar glukosa hasil hidrolisis enzim selulase dari substrat CMC dengan menggunakan metode NelsonSomogyi (Rahayu et al., 2014). Hasil sidik ragam menunjukkan bahwa interaksi jenis media produksi dan konsentrasi inokulum isolat bakteri $\mathrm{B} 2 \mathrm{~S} 8$ berpengaruh sangat nyata $(\mathrm{p}<0,01)$ terhadap aktivitas enzim selulase.

Tabel 2. Nilai rata-rata hasil analisis aktivitas endoglukonase U/mL

\begin{tabular}{lccccc}
\hline Media Produksi & \multicolumn{5}{c}{ Konsentrasi Sel Bakteri (\%) } \\
\cline { 2 - 6 } & 1 & 2 & 3 & 4 & 5 \\
\hline Media 1 & $0,0096 \pm$ & $0,0113 \pm$ & $0,0141 \pm$ & $0,0172 \pm$ & $0,0210 \pm$ \\
& $0,0000(\mathrm{k})$ & $0,0000(\mathrm{j})$ & $0,0002(\mathrm{i})$ & $0,0001(\mathrm{~g})$ & $0,0001(\mathrm{f})$ \\
Media 2 & $0,0083 \pm$ & $0,0102 \pm$ & $0,0134 \pm$ & $0,0156 \pm$ & $0,0207 \pm$ \\
& $0,0002(\mathrm{l})$ & $0,0002(\mathrm{k})$ & $0,0001(\mathrm{i})$ & $0,0002(\mathrm{~h})$ & $0,0000(\mathrm{f})$ \\
Media 3 & $0,0228 \pm$ & $0,0257 \pm$ & $0,0279 \pm$ & $0,0309 \pm$ & $0,0332 \pm$ \\
& $0,0002(\mathrm{e})$ & $0,0004(\mathrm{~d})$ & $0,0001(\mathrm{c})$ & $0,0001(\mathrm{~b})$ & $0,0000(\mathrm{a})$ \\
\hline
\end{tabular}

Keterangan: Huruf berbeda di belakang nilai rata-rata menunjukkan perbedaan yang sangat nyata pada taraf kesalahan $1 \%(\mathrm{p}<0,05)$.

Jenis Media 3 dengan konsentrasi inokulum bakteri $5 \%$ menghasilkan nilai ratarata aktivitas tertinggi yaitu sebesar 0,0332 $\mathrm{IU} / \mathrm{mL}$ dan jenis Media 2 dengan konsentrasi inokulum bakteri $1 \%$ menghasilkan nilai ratarata terendah yaitu $0,0083 \mathrm{IU} / \mathrm{mL}$ (Tabel 1). Hal ini menunjukkan konsentrasi inokulum yang bertambah besar. Menyebabkan aktivitas mikroorganisme dalam mendegradasi selulosa menjadi lebih cepat sehingga pertumbuhannya menjadi pesat. Pertumbuhan yang pesat pada mikroorganisme mengakibatkan pembentukan biomassa menjadi lebih besar 
(Sari et al., 2017). Vasudeo dan Lew (2011) memperoleh hasil selulase maksimum dari $B$. amyloliquefaciens UNPDV-22 pada $\mathrm{pH}$ 5,25, dan ukuran inokulum 4,95\% (v/v). Semakin tinggi aktivitas enzim semakin banyak gula pereduksi yang dihasilkan. Degradasi selulosa secara enzimatik sangat dibutuhkan untuk menghasilkan gula yang tinggi. Penggunaan media pepton akan memaksimalkan kecepatan metabolisme sel untuk mengkonsumsi gula lebih tinggi dan pepton juga sebagai sumber nitrogen utama pada media produksi sehingga menghasilkan pertumbuhan biomassa yang lebih tinggi (Sunaryanto, 2015). Komponen utama untuk berlangsungnya metabolisme sel mikroorganisme baik untuk pertumbuhan sel untuk menghasilkan metabolit tertentu sangatlah penting. Selain sumber karbon dan sumber nitrogen dalam media fermentasi juga terkandung element seperti $\mathrm{Fe}, \mathrm{Mn}, \mathrm{Ca}, \mathrm{Co}$ (Deesuth et al., 2012).

\section{Aktivitas enzim filter paperasi (eksoglukanase)}

Hasil sidik ragam menunjukkan bahwa perlakuan media dan konsentrasi inokulum bakteri isolat B2S8 berpengaruh sangat nyata $(\mathrm{p}<0,01)$ terhadap aktivitas enzim selulase.

Tabel 3. Nilai rata-rata hasil analisis aktivitas filter-paperasi (eksoglukanase) (IU/mL)

Media Produksi Konsentrasi Sel Bakteri (\%)

\begin{tabular}{llllll}
\cline { 2 - 5 } Media 1 & \multicolumn{1}{c}{1} & \multicolumn{1}{c}{2} & \multicolumn{1}{c}{3} & \multicolumn{1}{c}{4} & \multicolumn{1}{c}{5} \\
& $0,0015 \pm$ & $0,0017 \pm$ & $0,0022 \pm$ & $0,0029 \pm$ & $0,0030 \pm$ \\
Media 2 & $0,0000(\mathrm{j})$ & $0,0000(\mathrm{j})$ & $0,0000(\mathrm{~h})$ & $0,0000(\mathrm{f})$ & $0,0000(\mathrm{f})$ \\
& $0,0016 \pm$ & $0,0020 \pm$ & $0,0022 \pm$ & $0,0026 \pm$ & $0,0030 \pm$ \\
Media 3 & $0,0000(\mathrm{j})$ & $0,0000(\mathrm{i})$ & $0,0000(\mathrm{~h})$ & $0,0000(\mathrm{~g})$ & $0,0000(\mathrm{~g})$ \\
& $0,0033 \pm$ & $0,0035 \pm$ & $0,0042 \pm$ & $0,0052 \pm$ & $0,0060 \pm$ \\
& $0,0000(\mathrm{e})$ & $0,0000(\mathrm{~d})$ & $0,0000(\mathrm{c})$ & $0,0000(\mathrm{~b})$ & $0,0000(\mathrm{a})$ \\
\hline
\end{tabular}

Keterangan: Huruf berbeda di belakang nilai rata-rata menunjukkan perbedaan yang nyata pada taraf kesalahan 5\% $(\mathrm{p}<0,05)$.

Jenis Media 3 produksi enzim selulase kasar dengan konsentrasi inokulum bakteri isolat B2S8 5\% menghasilkan ratarata aktivitas enzim eksoglukanase tertinggi yaitu sebesar 0,0060 IU/mL. Sedangkan jenis Media 1 untuk produksi enzim eksoglukanase dengan konsentrasi inokulum bakteri selulolitik $1 \%$ menghasilkan rata-rata enzim eksoglukanase terendah sebesar 0,0015 IU/mL. Penggunaan jenis media (Tabel 3) dan konsentrasi inokulum bakteri isolat B2S8 berpengaruh nyata terhadap aktivitas enzim eksoglukanase yang dihasilkan menunjukkan perbedaan yang signifikan $(\mathrm{p}<0,05)$. Hasil hidrolisis selulosa dimanfaatkan oleh bakteri untuk pertumbuhan dalam media produksi enzim. Adapun penelitian Guha et al, (2013), menyatakan bahwa aktivitas xilanase
Bacillud sp. optimum pada media yang memakai pepton sebagai sumber nitrogennya dan menghasilkan aktivitas enzim sebesar 1,2 $\mathrm{IU} / \mathrm{mL}$. Kebutuhan sumber nitrogen setiap jenis mikroorganisme sangat spesifik dan berbeda-beda. Mikroorganisme yang sejenis tetapi dari sumber yang berbeda, akan berbeda pula kebutuhan sumber nitrogennya (Sari dan Kusdiyantini, 2017). Sumber karbon terbaik untuk fermentasi adalah $1 \%$ tepung jagung, sedangkan $2 \%$ senyawa pepton dan ragi adalah sumber nitrogen terbaik (Yang et al., 2014). Isolat yang memiliki aktivitas selulase pada substrat kertas saring, yaitu selulosa sintetik campuran antara selulosa amophours dan kristalin, menujukkan isolat tersebut memiliki sinergisme antara enzim end-1,4- $\beta$ - 
glukanase dan ekso-1,4- ß-glukanase untuk mereduksi selulosa menjadi glukosa.

\section{Kadar protein terlarut}

Hasil sidik ragam menunjukkan bahwa perlakuan jenis media dan konsentrasi inokulum bakteri isolat B2S8 antar perlakuan berpengaruh sangat nyata $(\mathrm{p}<0,01)$ terhadap kadar protein.

Tabel 4. Nilai rata-rata hasil analisis kadar protein $(\mathrm{mg} / \mathrm{mL})$

Media produksi

Konsentrasi sel Bakteri (\%)

\begin{tabular}{llllll}
\cline { 2 - 6 } & \multicolumn{1}{c}{1} & \multicolumn{1}{c}{2} & \multicolumn{1}{c}{3} & \multicolumn{1}{c}{4} & \multicolumn{1}{c}{5} \\
\hline Media 1 & $0,1196 \pm$ & $0,1533 \pm$ & $0,1687 \pm$ & $0,1880 \pm$ & $0,2150 \pm$ \\
& $0,0027(\mathrm{j})$ & $0,0013(\mathrm{i})$ & $0,0013(\mathrm{~h})$ & $0,0068(\mathrm{~g})$ & $0,0013(\mathrm{f})$ \\
Media 2 & $0,1196 \pm$ & $0,1610 \pm$ & $0,1668 \pm$ & $0,1977 \pm$ & $0,2189 \pm$ \\
& $0,0027(\mathrm{j})$ & $0,0013(\mathrm{hi})$ & $0,0013(\mathrm{hi})$ & $0,0041(\mathrm{~g})$ & $0,0041(\mathrm{f})$ \\
Media 3 & $0,2642 \pm$ & $0,3365 \pm$ & $0,4021 \pm$ & $0,5120 \pm$ & $0,5670 \pm$ \\
& $0,0055(\mathrm{e})$ & $0,0013(\mathrm{~d})$ & $0,0013(\mathrm{c})$ & $0,0014(\mathrm{~b})$ & $0,0081(\mathrm{a})$ \\
\hline
\end{tabular}

Keterangan: Huruf berbeda di belakang nilai rata-rata menunjukkan perbedaan yang nyata pada taraf kesalahan $5 \%$ $(\mathrm{p}<0,05)$.

Jenis Media 3 produksi enzim selulase kasar dengan konsentrasi inokulum bakteri isolat B2S8 5\% menghasilkan ratarata kadar protein tertinggi yaitu 0,5670 $\mathrm{mg} / \mathrm{mL}$ sedangkan kadar protein terendah pada media pertama dan kedua untuk produksi enzim selulase dengan konsentrasi inokulum bakteri selulolitik $1 \%$ adalah $0,1196 \mathrm{mg} / \mathrm{mL}$. Penggunaan media (Tabel 1) dan konsentrasi inokulum bakteri isolat B2S8 berpengaruh nyata terhadap kadar protein terlarut pada enzim selulase kasar yang dihasilkan menunjukkan perbedaan yang signifikan $(\mathrm{p}<0,05)$. Pada penelitian ini kadar protein terlarut dalam filtrat enzim kasar diasumsikan sebagai protein enzim selulase.
Penambahan bakteri selulolitik berpengaruh terhadap peningkatan kadar protein pada pembuatan selulase. Karbohidrat terlarut pada substrat dimanfaatkan oleh bakteri selulolitik sebagai nutrisi untuk pertumbuhannya sehingga dalam masa inkubasi bakteri selulolitik akan berkembang lebih banyak (Rastogi et al., 2009).

\section{Aktivitas spesifik endoglukanase}

Berdasarkan hasil sidik ragam menunjukkan bahwa interaksi perlakuan jenis media produksi enzim selulase kasar dan konsentrasi inokulum bakteri berpengaruh sangat nyata $(\mathrm{p}<0,01)$ terhadap aktivitas spesifik endoglukanase.

Tabel 5. Nilai rata-rata hasil analisis aktivitas spesifik endoglukanase IU/mg

Media Produksi Konsentrasi Sel Bakteri (\%)

\begin{tabular}{cccccc} 
& 1 & 2 & 3 & 4 & 5 \\
\cline { 2 - 6 } Media 1 & $0,0807 \pm$ & $0,0629 \pm$ & $0,0572 \pm$ & $0,0513 \pm$ & $0,0448 \pm$ \\
& $0,0017(\mathrm{a})$ & $0,0004(\mathrm{~b})$ & $0,0004(\mathrm{c})$ & $0,0018(\mathrm{~d})$ & $0,0003(\mathrm{e})$ \\
Media 2 & $0,0807 \pm$ & $0,0599 \pm$ & $0,0578 \pm$ & $0,0488 \pm$ & $0,0441 \pm$ \\
& $0,0017(\mathrm{a})$ & $0,0004(\mathrm{bc})$ & $0,0004(\mathrm{c})$ & $0,0010(\mathrm{~d})$ & $0,0007(\mathrm{e})$ \\
Media 3 & $0,0365 \pm$ & $0,0287 \pm$ & $0,0240 \pm$ & $0,0188 \pm$ & $0,0170 \pm$ \\
& $0,0007(\mathrm{f})$ & $0,0000(\mathrm{~g})$ & $0,0000(\mathrm{~h})$ & $0,0000(\mathrm{i})$ & $0,0002(\mathrm{i})$ \\
\hline
\end{tabular}

Keterangan: Huruf berbeda di belakang nilai rata-rata menunjukkan perbedaan yang nyata pada taraf kesalahan $5 \%$ $(\mathrm{p}<0,05)$. 
Tabel 5 menunjukkan bahwa nilai rata-rata aktivitas spesifik endoglukanase tertinggi $0,0807 \mathrm{IU} / \mathrm{mg}$ yang diperoleh dari interaksi perlakuan media pertama dan kedua dengan konsentrasi inokulum bakteri 1\%, sedangkan nilai terendah $0,0170 \mathrm{IU} / \mathrm{mg}$, diperoleh dari perlakuan media ketiga dengan konsentrasi inokulum bakteri 5\%, lebih tinggi kadar protein yang dihasilkan dari pada peningkatan aktivitas enzim, sehingga menghasilkan nilai perbandingan yang tinggi sebagai aktivitas spesifiknya. Pada interaksi perlakuan konsentrasi inokulum bakteri 5\% dan konsentrasi inokulum bakteri menghasilkan perbandingan yang rendah, sehingga menghasilkan aktivitas spesifik yang rendah pula. Hal ini menunjukkan aktivitas enzim yang tinggi belum tentu menghasilkan aktivitas spesifik yang tinggi tergantung pada kadar protein yang dihasilkan karena aktivitas spesifik diperoleh dengan membagikan aktivitas enzim dengan kadar protein yang dihasilkan. semakin besar kadar protein maka aktivitas spesifik suatu enzim akan semakin kecil (Richardson et al.,2002).

\section{Aktivitas spesifik eksoglukanase}

Berdasarkan hasil sidik ragam menunjukkan bahwa interaksi perlakuan jenis media produksi enzim selulase kasar dan konsentrasi inokulum bakteri berpengaruh sangat nyata $(\mathrm{p}<0,05)$ terhadap aktivitas spesifik eksoglukanase.

Tabel 6. Nilai rata-rata hasil analisis aktivitas spesifik eksoglukanase (IU/mL)

\begin{tabular}{cccccc}
\hline Media Produksi & \multicolumn{5}{c}{ Konsentrasi Sel Bakteri (\%) } \\
\cline { 2 - 6 } & 1 & 2 & 3 & 4 & 5 \\
\hline Media 1 & $0,0123 \pm$ & $0,0096 \pm$ & $0,0087 \pm$ & $0,0078 \pm$ & $0,0068 \pm$ \\
& $0,0002(\mathrm{a})$ & $0,0001(\mathrm{~b})$ & $0,0000(\mathrm{c})$ & $0,0002(\mathrm{~d})$ & $0,0000(\mathrm{ef})$ \\
Media 2 & $0,0123 \pm$ & $0,0091 \pm$ & $0,0088 \pm$ & $0,0074 \pm$ & $0,0067 \pm$ \\
& $0,0002(\mathrm{a})$ & $0,0000(\mathrm{bc})$ & $0,0000(\mathrm{c})$ & $0,0001(\mathrm{de})$ & $0,0001(\mathrm{f})$ \\
Media 3 & $0,0056 \pm$ & $0,0044 \pm$ & $0,0037 \pm$ & $0,0029 \pm$ & $0,0026 \pm$ \\
& $0,0001(\mathrm{~g})$ & $0,0000(\mathrm{~h})$ & $0,0000(\mathrm{i})$ & $0,0000(\mathrm{j})$ & $0,0000(\mathrm{j})$ \\
\hline
\end{tabular}

Keterangan: Huruf berbeda di belakang nilai rata-rata menunjukkan perbedaan yang nyata pada taraf kesalahan $5 \%$ $(\mathrm{p}<0,05)$.

Tabel 6 menunjukkan bahwa nilai rata-rata aktivitas spesifik endoglukanase tertinggi $0,0123 \mathrm{IU} / \mathrm{mg}$ yang diperoleh dari interaksi perlakuan media pertama dan kedua dengan konsentrasi inokulum bakteri $1 \%$, sedangkan nilai terendah $0,0026 \mathrm{IU} / \mathrm{mg}$ diperoleh dari perlakuan media ketiga dengan konsentrasi inokulum bakteri 5\%. Hal ini disebabkan karena terjadinya peningkatan filter paperase pada interaksi perlakuan media ketiga dengan konsentrasi inokulum bakteri $1 \%$ lebih tinggi dari pada peningkatan kadar protein terlarut, sehingga menghasilkan nilai perbandingan yang lebih tinggi sebagai aktivitas spesifik. Pada interaksi perlakuan jenis media ketiga dengan konsentrasi inokulum bakteri 5\% menghasilkan aktivitas spesifik yang lebih rendah. Hal ini disebabkan peningkatan aktivitas filter paperase yang lebih rendah daripada penurunan kadar protein terlarutnya sehingga aktivitas spesifik yang dihasilkan lebih rendah. Aktivitas spesifik enzim menunjukkan kemurnian suatu enzim. Semakin tinggi aktivitas spesifik, maka semakin tinggi pula tingkat kemurnian enzim tersebut. Hal ini disebabkan karena hilangannya protein non-enzim pada beberapa tahap pemisahan yang dilalui dalam pemurnian enzim (Humbird et al., 2011).

KESIMPULAN DAN SARAN 


\section{Kesimpulan}

Berdasarkan hasil penelitian yang telah dilakukan dapat disimpulkan, antara lain:

1. Perlakuan media dan konsentrasi inokulum bakteri isolat B2S8 pada produksi enzim selulase kasar berpengaruh sangat nyata terhadap aktivitas enzim endoglukananse dan enzim endoglukananse.

2. Perlakuan media dengan konsentrasi inokulum bakteri selulolitik isolat B2S8 dengan konsentrasi inokulum bakteri 5\% merupakan perlakuan terbaik untuk memproduksi enzim selulase kasar dengan menghasilkan aktivitas enzim endoglukananse sebesar 0,0332 IU/mL, aktivitas enzim eksoglukananse sebesar $0,0060 \mathrm{IU} / \mathrm{mL}$, kadar protein terlarut sebesar $0,5670 \mathrm{mg} / \mathrm{mL}$, aktivitas spesifik endoglukananse sebesar 0,0807 IU/mg dan aktivitas spesifik eksoglukananse sebesar 0,0123 IU/mg.

\section{Saran}

Perlu dilakukan penelitian lebih lanjut mengenai analisis konsentrasi substrat brangkasan jagung dan lama fermentasi terhadap aktivitas enzim selulase kasar dari bakteri isolat B2S8.

\section{DAFTAR PUSTAKA}

Anindyawati, T. 2010. Potensi Selulase dalam Mendegradasi Lignoselulosa Limbah Pertanian untuk Pupuk organik. Jurnal Selulosa, 45(2):175 180.

Atlas, R. M. 2010. Handbook of Microbiological Media. CRC press, Boca Raton, pp. 145 - 1463.

Coperland, R. A. 2000. Enzymes 2nd edition: A Practical Introduction to Structure, Mechanism and Data Analysis. A Jhon Wiley and Sons, Inc.
Publication. New York.

Dar, A.M., K.D. Pawar., J.P. Jadhav., and R.S. Pandit. 2015. Isolation of Cellulytic Bacteria from the Gastrointestinal tract of Achatina fulica (gastroda: pulmonata) and their Evaluation form Cellulose Biodegration. International Biodeterioration and Biodegradation. 98:73 - 80 .

Deesuth, O., P. P. Laopaiboon. L. Jaisil. Laopaiboon. 2012. Optimization of Nitrogen and Metal ions Supplementation for Very High Gravity Bioethanol Fermentation from Sweet Sorghum Juice Using an Orthogonal Array Design. Enegies 5(2):3178 - 3197 .

Duza, M.B, and S.A. Mastan. 2013. Isolation, Characterization and Screening of Enzyme Producing Bacteria from Different Soil Samples. International Journal of pharma and bio sciences, $4(2): 813-824$.

Guha, S., S. Bhutty., S.M.P. Kurana., U.K. Kohli. 2013. Optimization of Cultural Conditions for Production of ThermoAlkali Tolerant Xylanase from Bacillus sp. International Journal of Reseach in Pure and Applied Microbiology. 3(4):116 - 120.

Gunam, I. B. W., Aryanta, W. R. \& Darma, I. B. N. S. 2011. Produksi Selulase Kasar dari Kapang Trichoderma viride dengan Perlakuan Konsentrasi Substrat Ampas Tebu dan Lama Fermentasi. Jurnal Biologi Udayana, 15(2).

Gunam, I. B. W., N. S Antara., A.A.M.D Anggreni., Y. Setiyo., I.P.E Wiguna., I.M.M Wijaya., And I.W.W.P Putra., 2019. Chemical Pretreatment of 
Lignocellulosic Wastes for Cellulose Production by Aspergillus niger FNU 6018. Proceedings of the 2nd International Conference on Biosciences and Medical Engineering (ICBME2019). 020040 - 2.

Gupta, P., K. Samant., and A. Sahu. 2012. Isolation of Cellulose-Degrading Bacteria and Determination of their Cellulolytic Potential. International Journal of Microbiology. 10:1 - 5.

Hartanti. 2010. Isolasi dan Seleksi Bakteri Selulolitik Termofilik dari Kawah Air Panas Gunung Pancar, Bogor. Skripsi FMIPA IPB, Bogor.

Hoa, B. T. And P. V. Hung. 2013. Optimization of Nutrional Composition and Fermentation Conditions for Cellulase and Pectinase Production for Cellulase and Pectinase Production by Aspergillus oryzae using Respons Surface Methodology. International Food Research Journal. 20(6):3269 3274.

Humbird, D., R. Davis., L. Tao., C. Kinchin., D. Hsu., A. Aden., P. Schoen., J. Lukas., B. Olthof., M. Worley., and D. Sexton. 2011. Process Design and Economics for biochemical Conversion of Lignocellulosic Biomass to Ethanol: Dilute-acid Pretreatment and Enzymatic Hydrolysis of Corn Stover. National Renewable Energy Lab.(NREL), Golden, CO (United States). No. NREL/TP-5100 - 47764.

Kusumaningrum, A., . I.B.W. Gunam., dan M.M Wijaya. 2019. Optimasi Suhu dan $\mathrm{pH}$ Terhadap Aktivitas Enzim Endoglukanase Menggunakan Response Sruface Methodology (RSM). Jurnal Rekayasa dan Manajement Industri. 7(2):243 - 253.
Lowry, Rosenbrough, Farr, Randall. 1990. Protein Measurement with the Folin Phenol Reagent. Kluwer Academic Publishers. New York.

Lynd, L. R., P.J. Weimer., W.H. VanZyl.,and I.S. Pretorius. 2002. Microbial Cellulosa Utilization: Fundamentals and Biotechnology. Microbiology Mol. Biol. 56:506 577.

Mosier, N., C. Wynman. 2005. Features of Promising Technologies for Pretreatment of Lignocellulosic Biomass. Bioresource Technology. 96(6):673 - 686.

Nabanan, M., I.B.W. Gunam., I.M.M. Wijaya. 2019. Produksi Enzim Selulase Kasar dari Bakteri Selulolitik. Jurnal Rekayasa dan Manajemen Agroindustri. 7(2):190 199.

Rahayu, A.G., Y. Haryani., dan F. Puspita. 2014. Uji aktivitas selulolitik dari tiga isolat bakteri Bacillus sp. galur lokal Riau. Jurnal Online Mahasiswa Fakultas Matematika dan Ilmu Pengetahuan Alam Universitas Riau, 1(2): $12-20$.

Rastogi, G., Muppidi, G.L., Gurram, R.N., Adhikari, A., Bischoff, K.M., Hughes, S.R., Apel, W.A., Bang, S.S., Dixon, D.J. and Sani, R.K. 2009. Isolation and Characterization of Cellulose-Degrading Bacteria from the Deep Subsurface of the Homestake Gold Mine, Lead, South Dakota, USA. Journal of industrial microbiology and biotechnology. 36(4): 585-697.

Richardson, T.H., X. Tan., G. Frey., W. Callen., M. Cabell., D. Lam., J. Macomber., J.M Short., D.E. Robertson, and C. Miller. 2002. A Novel, High Performance Enzyme for 
Starch Liquefaction Discovery and Optimization of a Low $\mathrm{pH}$, Thermostable $\alpha$-amylase. Journal of Biological Chemistry. 277(29): 26501 $-26507$.

Sari, A. R., E. Kusdiyantini., dan M.I. Rukmi. 2017. Produksi Selulase Oleh Kapang Aspergillus sp. Hasil Isolasi dari Limbah Pengolahan Sagu (Metroxylon sp.) dengan Variasi Konsentrasi Inokulum pada Fermentasi Terendam Statis. Jurnal Akademika Biologi. 6(1): 11 - 20.

Sari, R., dan R. Prayudyaningsih. 2015. Rhizobium: Pemanfaatannya sebagai Bakteri Penambat Nitrogen. Buletin Eboni. 12(1):51 - 64 .

Sood. S., S. Bhat., R. Shinghai., And A. Kumar. 2011. Upstream Processing Inoculum Preparation in: Murray Moo-Young (ed.). Comprehensive Biotechnology, second edition Elsivier. 2: $151-164$.
Sunaryanto, R., dan B. H. Handayani. 2015. Penentuan Kombinasi Medium Terbaik Galaktosa dan Nitrogen pada Proses Produksi Etanol. Jurnal Bioteknologi dan Biosains Indonesia. 2(1):2442 - 2606 .

Umiyasih, U. dan E. Wina. 2008. Pengolahan dan Nilai Nutrisi Limbah Tanaman Jagung sebagai Pakan Ternak Ruminansia. Wartazoa. 18(3):127 136.

Wijaya, Rudi. 2002. Karakterisasi Enzim Serupa Tripsin dari cacing Tanah, Tesis, Sekolah Pascasarjana, Institut Pertanian Bogor. Bogor.

Yang, W., F. Meng., J. Peng., P. Han., F. Fang., L. Ma., and B. Cao. 2014. Isolation and Identification of a Cellulolytic Bacterium from the Tibetan Pig's Intestine and Investigation of its Cellulase Production. Electronic Journal of Biotechnology. 11(3): 262-267. 